\title{
PENGARUH MODEL PEMBELAJARAN SNOWBALL THROWING TERHADAP KEMAMPUAN KOMUNIKASI MATEMATIS SISWA PADA MATERI MATRIKS KELAS XI SMK NEGERI 1 STABAT TAHUN PELAJARAN 2019/2020
}

\author{
Evi Ramadhani Siregar ${ }^{1}$, Mardiati $^{2}$ \\ Program Studi Pendidikan Matematika STKIP Budidaya Binjai, Indonesia \\ ${ }^{1)}$ E-mail : eviramadhanisiregar@gmail.com \\ ${ }^{2)}$ E-mail : mardiati2208@gmail.com
}

\begin{abstract}
ABSTRAK
Penelitian ini bertujuan untuk mengetahui apakah ada pengaruh signifikan model pembelajaran Snowball Throwing terhadap kemampuan komunikasi matematis siswa kelas XI SMK Negeri 1 Stabat Tahun Pelajaran 2019/2020. Populasi dalam penelitian ini adalah siswa kelas XI SMK Negeri 1 Stabat Tahun Pelajaran 2019/2020. Sedangkan dalam sampel ini terdiri dari 2 kelas. Kelas XI-1 sebagai kelas eksperimen berjumlah 32 orang siswa, pada kelas XI-2 sebagai kelas kontrol berjumlah 32 orang siswa. Kelas eksperimen pembelajaran dengan menggunakan pembelajaran Snowball Throwing dan pada kelas kontrol menggunakan pembelajaran langsung. Jenis penelitian ini adalah penelitian eksperimen dengan pretest dan posttest, sebagai alat pengumpul data digunakan tes kemampuan komunikasi matematis yang terdiri dari 5 butir soal uraian. Uji hipotesis yang digunakan adalah uji regresi linier sederhana. Berdasarkan uji hipotesis didapat $\mathrm{F}_{\text {hitung }}>$ $\mathrm{F}_{\text {tabel }}$ yaitu 4,37 > 4,16 pada uji keberatian, maka $\mathrm{H}_{0}$ ditolak dan $\mathrm{H}_{\mathrm{a}}$ diterima sehingga arah koefisien berarti, uji kelinieritas apabila $\mathrm{F}_{\text {hitung }}<\mathrm{F}_{\text {tabel }}$ yaitu $0,577<4,16$ maka $\mathrm{H}_{0}$ ditolak dan $\mathrm{H}_{\mathrm{a}}$ diterima maka linier, diperoleh $r_{\text {hitung }}>r_{\text {tabel }}$ yaitu 103,725 $>0,3494$ maka $(r \neq 0)$ dengan taraf signifikan 5\%. Sehingga dapat diambil kesimpulan bahwa terdapat pengaruh model pembelajaran snowball throwing terhadap kemampuan komunikasi matematis siswa pada materi matriks kelas XI SMK Negeri 1 Stabat tahun pelajaran 2019/2020.
\end{abstract}

\section{Kata kunci : Snowball Throwing, Kemampuan Komunikasi Matematis}

\section{PENDAHULUAN}

Pendidikan adalah satu-satunya aset untuk membangun sumber daya manusia yang berkualitas. Lewat pendidikan bermutu, bangsa dan negara akan terjunjung tinggi martabat dimata dunia. Mengetahui betapa pentingnya pendidikan bagi setiap orang, terutama terhadap pendidikan formal. Sekolah adalah lembaga pendidikan formal. Salah satu ilmu pendidikan yang dipelajari di sekolah adalah pendidikan matematika. Pendidikan matematika merupakan hal yang penting didapatkan dalam proses pembelajaran di sekolah, terutama pada jenjang pendidikan dasar, menengah dan atas. Matematika sebagai salah satu mata pelajaran di sekolah dinilai cukup memegang peranan penting dalam membentuk siswa menjadi berkualitas, karena matematika merupakan suatu sarana berpikir untuk mengkaji sesuatu secara logis dan sistematis. Melihat begitu pentingnya peranan matematika, maka dari itu pembelajaran matematika perlu di kembangkan demi tercapainya tujuan pembelajaran yang diinginkan, salah satunya adalah kemampuan komunikasi matematis yang ada pada siswa.

Komunikasi memainkan peranan yang penting dalam membantu siswa bukan saja dalam membina konsep melainkan membina perkaitan antara ide dan bahasa abstrak dengan simbol matematika. Siswa juga harus diperkenankan untuk mempunyai ide-ide mereka secara bertutur, menulis, melukis gambar atau grafik. Menyadari hal tersebut 
maka kemampuan komunikasi matematis merupakan salah satu bagian yang utama yang hendak dicapai dalam tujuan pembelajaran matematika dan harus dimiliki oleh setiap siswa. Kemampuan komunikasi matematis dipandang sebagai cara bernalar karena terbentuk sebagai hasil pemikiran manusia yang berhubungan dengan ide, proses dan penalaran. Kemampuan komunikasi matematis berguna untuk melatih daya pikir seseorang, yang membuatnya kreatif dalam memecahkan masalah-masalah. Kemampuan komunikasi matematis secara tidak langsung bukan menjadi tujuan dalam penyelesaian masalah dalam matematika, karena matematika adalah mata pelajaran yang sangat susah dan momok bagi siswa sehingga hasil belajar siswa terhadap pembelajaran matematika tergolong rendah. Pada kenyataannya bukan materi pelajaran saja yang sukar untuk dipelajari siswa. Namun seorang pendidik memiliki kemungkinan gagal dalam menyampaikan materi dikelas, ini dikarenakan proses belajar mengajar kurang menarik perhatian dan aktifitas peserta didik dalam mengikuti pelajaran khususnya pada pelajaran matematika. Terkadang pendidik mengalami kesulitan dalam hal menyampaikan materi kepada peserta didik, sehingga hasil belajar yang diperoleh peserta didik pada pelajaran matematika terbilang rendah.

Berdasarkan hasil observasi, pembelajaran matematika di SMK Negeri 1 Stabat ditemukan beberapa kelemahan, diantaranya adalah prestasi belajar yang masih rendah pada pelajaran matematika. Hal ini ditunjukan dengan hasil belajar matematika siswa di SMK Negeri 1 Stabat rata-rata dibawah nilai KKM yaitu nilai 75 , yang ditentukan oleh pihak sekolah.

Selain itu dari hasil tes awal yang dilakukan peneliti pada siswa kelas XI-II di SMK Negeri 1 Stabat yang berjumlah 32 siswa diperoleh data kemampuan komunikasi matematis yang masih rendah. Rendahnya komunikasi matematis siswa tersebut dapat dilihat dari salah satu jawaban siswa pada tes awal yang diberikan peneliti yaitu dengan soal sebagai berikut:

1. Dua buah matriks A dan B masing-masing berturut-turut:

$$
A=\left(\begin{array}{ll}
6 & 7 \\
8 & 9
\end{array}\right), \quad B=\left(\begin{array}{ll}
1 & 2 \\
3 & 4
\end{array}\right)
$$

Maka, tentukan A+B ?

2. Perhatikan matriks $P$ dan matriks $Q$, berikut ini.

$$
P=\left(\begin{array}{ll}
1 & 2 \\
3 & 4
\end{array}\right), \quad Q=\left(\begin{array}{ll}
a & x \\
b & y
\end{array}\right)
$$

Tentukan matriks PQ ?

Jawaban siswa :

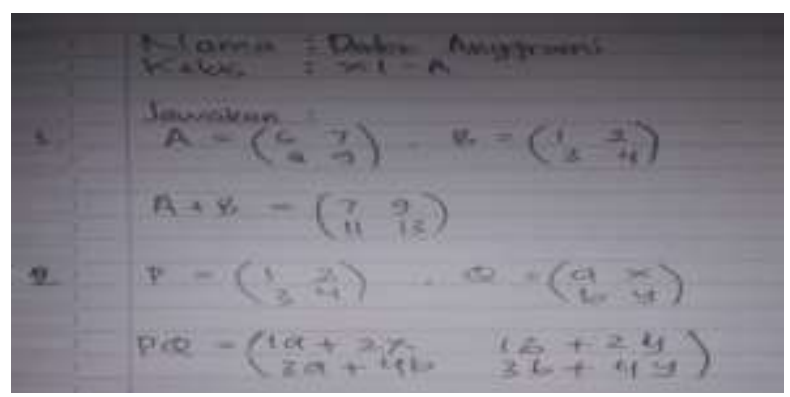

Gambar 1. Jawaban Siswa

Dari jawaban siswa terlihat bahwa siswa masih kesulitan menjawabsoal pada nomor 1 dan 2. Pada nomor 1 siswa masih kesulitan untuk mengikuti aturan menjawab yang baik dan benar. Walaupun hasil jawabannya itu benar. Sedangkan pada nomor 2 siswa benar-benar sangat kesulitan dalam soal tersebut. Siswa tidak bisa membedakan bilangan (entri pada matriks) yang seharusnya pasangan perkaliannya. Dari 32 siswa tidak ada yang memperoleh nilai dengan rentang 100, 12 siswa memperoleh nilai dengan rentang 60 , dan 15 siswa memperoleh nilai dengan rentang 0 . Dari hasil tes awal yang dilakukan peneliti terlihat bahwa kemampuan komunikasi matematis siswa tersebut sangat rendah. Hal ini dilihat dari criteria ketuntasan minimal siswa kelas XI SMK Negeri 1 Stabat yaitu nilai 75. Selain rendahnya kemampuan komunikasi 
matematis siswa. Kebanyakan guru di SMK Negeri 1 Stabat masih menggunakan metode pembelajaran konvensional yaitu metode ceramah, yang mengakibatkan kemampuan komunikasi matematis siswa menjadi sulit dalam memahami pelajaran matematika, sehingga proses pembelajaran cenderung membosankan, dapat menyebabkan siswa menjadi kurang aktif dan menciptakan suasana yang membuat siswa takut untuk belajar matematika.

Dengan hasil belajar yang kurang maksimal, salah satu solusi untuk pemecahan masalah tersebut adalah dengan menggunakan model pembelajaran matematika yang mampu meningkatkan kemampuan komunikasi siswa dalam pembelajaran matematika. Penggunaan model pembelajaran snowball throwing merupakan satu alternatif untuk meningkatkan kemampuan komunikasi siswa.

Snowball artinya bola salju, sedangkan Throwing artinya melempar. Snowball throwing secara keseluruhan dapat diartikan melempar bola salju. Menurut Aris Shoimin model pembelajaran snowball throwing merupakan pengembangan dari model pembelajaran diskusi dan merupakan bagian dari model pembelajaran kooperatif. Hanya saja pada model ini, kegiatan belajar dapat di atur sedemikian rupa sehingga proses belajar mengajar dapat berlangsung lebih menyenangkan.

Langkah-langkah model pembelajaran snowball throwing menurut Aris Shoimin adalah :

Tabel 1. Fase Pembelajaran Snowball Throwing

\begin{tabular}{|c|c|}
\hline Fase & Tingkah Laku Guru \\
\hline $\begin{array}{l}\text { Fase } 1 \\
\text { Menyampaikan } \\
\text { tujuan dan } \\
\text { memotivasi siswa }\end{array}$ & \begin{tabular}{ll} 
& \multicolumn{2}{l}{ Menyampaikan } \\
seluruh tujuan & dalam pembelajaran \\
dan memotivasi \\
siswa.
\end{tabular} \\
\hline $\begin{array}{l}\text { Fase } 2 \\
\text { Menyajikan }\end{array}$ & $\begin{array}{ll} & \text { Menyajikan } \\
\text { informasi tentang }\end{array}$ \\
\hline
\end{tabular}

\begin{tabular}{ll}
\hline informasi & \multicolumn{2}{l}{ materi pembelajaran } \\
& siswa. \\
\hline Fase 3 & Memberi informasi \\
Mengorganisasikan & kepada siswa \\
siswa ke dalam & tentang prosedur \\
kelompok- & pelaksanaan \\
kelompok belajar & $\begin{array}{l}\text { pembelajaran } \\
\text { snowball throwing. }\end{array}$ \\
\hline
\end{tabular}

- Membagi siswa ke dalam kelompokkelompok belajar yang terdiri dari 5 orang siswa.

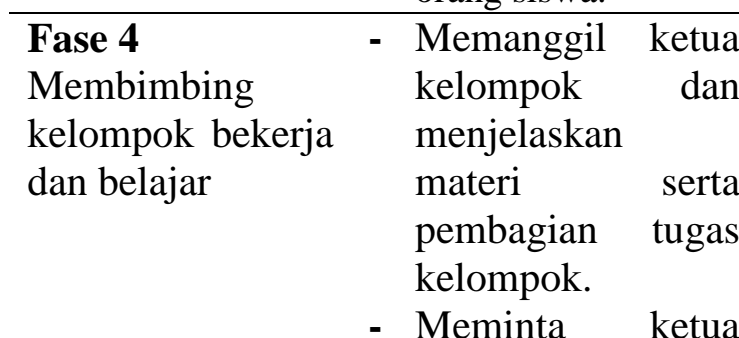
kelompok kembali ke kelompoknya masing-masing untuk mendiskusikan tugas yang diberikan guru dengan anggota kelompok.

- Memberikan selembar kertas kepada setiap kelompok dan meminta kelompok tersebut menulis pertanyaan sesuai dengan materi yang dijelaskan guru.

- Meminta setiap kelompok untuk menggulung dan melemparkan pertanyaan yang telah ditulis pada kertas kepada 
kelompok lain.

- Meminta setiap

kelompok

menuliskan

jawaban

atas

pertanyaan yang

didapatkan dari

kelompok lain

pada kertas kerja tersebut

\begin{tabular}{ll}
\hline Fase 5 & Guru meminta \\
Evaluasi & setiap \\
& kelompok \\
& untuk \\
& membacakan \\
& jawaban atas \\
& pertanyaan \\
& yang diterima \\
& dari kelompok \\
& lain. \\
\hline Fase 6 & Memberikan \\
Memberi & penilaian \\
penilaian/penghargaan & terhadap hasil \\
& kerja kelompok \\
\hline
\end{tabular}

Kemampuan

komunikasi

matematis adalah kemampuan siswa berkomunikasi dalam matematika secara lisan maupun tulisan yang meliputi keahlihan membaca, mendengar dan mengevaluasi ide, simbol, istilah serta informasi matematika. Dalam komunikasi matematis terdapat lima aspek yang sangat penting, yaitu :

1) Merepresentasikan, siswa menunjukan kembali suatu idea tau suatu masalah dalam bentuk baru.

2) Membaca, siswa dapat membaca teks secara aktif untuk mencari jawaban atas pertanyaan-pertanyaan yang telah disusun.

3) Berdiskusi, merupakan pertemuan ilmiah untuk bertukar pikiran mengenai suatu masalah.

4) Menulis, kegiatan menulis matematika lebih ditekankan pada mengekspresikan ide-ide matematika.

5) Mendengar, siswa dapat menangkap suara atau bunyi dengan telinga yang kemudian member respon terhadap apa yang didengar.

Adapun indikator yang menunjukan kemampuan komunikasi matematis menurut National Center Teaching Matematcs diantaranya : 1) dapat menyatakan ide matematik dengan lisan, tulisan, mendemostrasikan dan menggambarkan dalam bentuk visual, 2) dapat memahami menginterprestasikan dan menilai ide matematika yang disajikan dalam bentuk tulisan atau lisan, 3) dapat menggunakan bahasa notasi, notasi dan struktur matematik yang menyajikan ide, menggambarkan hubungan perbuatan model.

\section{METODE PENELITIAN}

Jenis penelitian yang digunakan adalah penelitian eksperimental semu atau Quasi Eksperimen. Quasi eksperiment didefinisikan sebagai eskperimen yang memiliki perlakukan, pengukuran dampak, unit eksperimen namun tidak menggunakan penugasan acak, melainkan sesuai dengan kelas yang sudah ada pada sekolah yang telah dipilih.

Penelitian ini menggunakan pendekatan kuantitatif, sedangkan desain yang digunakan 
dalam penelitian ini adalah desain kelompok kontrol tidak ekuivalen (non equivalent control group design) yang merupakan bagian dari penelitian eksperimental semu. Pada desain penelitian ini menggunakan dua kelas, yaitu satu kelas sebagai kelas kontrol dan satu kelas sebagai kelas eksperimen. Desain ini dapat digambarkan sebagai berikut :

\begin{tabular}{llll} 
Kelas Eksperimen & $O_{1}$ & $x$ & $O_{2}$ \\
\cline { 2 - 3 } Kelas Kontrol & $O_{1}$ & & $O_{2}$
\end{tabular}

(Sumber : Sugiyono)

Keterangan :

$O_{1}=$ pre test sebelum pemberian pembelajaran menggunakan model pembelajaran snowball throwing pada kelas eksperimen dan kelas kontrol.

$\mathrm{O}_{2}=$ post test sesudah pemberian pembelajaran menggunakan model pembelajaran snowball throwing pada kelas eksperimen dan kelas kontrol.

$X=$ pemberian model pembelajaran snowball throwing

Populasi dalam penelitian ini adalah seluruh siswa kelas XI SMK Negeri 1 Stabat Tahun Pelajaran 2019/2020 sebanyak 2 kelas. Sampel dalam penelitian ini dipilih dengan teknik random sampling. Peneliti melakukan sistem random (acak) yaitu dengan sistem undian (untung-untungan) maka terpilihlah kelas XI-1 yang berjumlah 32 siswa sebagai sampel kelas eksperimen yang diberikan perlakuan model pembelajaran snowball throwing dan kelas XI-2 yang berjumlah 32 siswa sebagai kelas kontrol tanpa diberikan perlakuan model pembelajaran snowball throwing.

Dalam penelitian ini ada dua variabel yang akan diteliti, variabel bebas dalam penelitian ini adalah model pembelajaran snowball throwing. Variabel terikat dalam penelitian ini adalah kemampuan komunikasi matematis siswa.

\section{HASIL DAN PEMBAHASAN}

Berdasarkan penelitian yang telah dilakukan, diperoleh data kemampuan komunikasi matematis siswa dari hasil pretest dan posttest. Kemudian dilakukan uji normalitas dan homogenitas data pretest dan posttest pada kelas eksperimen dan kelas kontrol.

Dalam penelitian ini, uji normalitas yang digunakan adalah uji lilifors, dengan ketetntuan bahwa data berasal dari populasi yang berdistribusi normal jika memenuhi kriteria $\mathrm{L}_{\text {hitung }}<\mathrm{L}_{\text {tabel }}$ diukur para taraf signifikansi dan tingkat kepercayaan tertentu. Uji normalitas data pretest kelas eksperimen diperoleh bahwa kelas eksperimen diperoleh $(0,008<0,1568)$ sedangkan pada kelas kontrol $(0,18665<$ $0,1568)$. Uji normalitas data posttest diperoleh bahwa kelas eksperimen diperoleh $(0,13945<$ $0,1568)$ sedangkan pada kelas kontrol $(0,07695$ $<0,1568)$.

Untuk menguji homogenitas dari data yang diperoleh selama penelitian, digunakan uji fisher. Hasil perhitungan homogenitas pretest menunjukan populasi penelitian ini homogen maka diperoleh hasil $F_{\text {hitung }}$ pada kelas eksperimen adalah 1,7433 sedangkan nilai $F_{\text {tabel }}$ adalah 1,816. Dengan demikian $\mathrm{F}_{\text {hitung }}<\mathrm{F}_{\text {tabel }}$ ini berarti $\mathrm{H}_{0}$ tidak ditolak, dengan demikian dapat disimpulkan bahwa populasi homogen. Hasil perhitungan homogenitas postest menunjukan populasi penelitian ini homogen maka diperoleh hasil $\mathrm{F}_{\text {hitung }}$ pada kelas eksperimen adalah 1,1184 sedangkan nilai $F_{\text {tabel }}$ adalah 1,816. Dengan demikian $\mathrm{F}_{\text {hitung }}<\mathrm{F}_{\text {tabel }}$ ini berarti $\mathrm{H}_{0}$ tidak ditolak, dengan demikian dapat disimpulkan bahwa populasi homogen.

Pengujian hipotesis ini diujikan dengan menggunakan uji regresi sederhana. Dari hasil perhitungan yang telah dilakukan pada akhirnya didapatkan persamaan regresi sederhana yaitu $\hat{Y}=76,782+0,05123 X$, selanjutnya dilakukan untuk uji keberartian, uji linieritas, dan uji hipotesis dimana seluruh hasilnya pada tabel 2 berikut.

Tabel 2. Daftar Analisis Varians Regresi Linier Sederhana

\begin{tabular}{lrrrr}
\hline Varians & Dk & JK & KT & F \\
\hline Total & 32 & 204036 & 204036 & 4,37 \\
\hline
\end{tabular}




\begin{tabular}{|c|c|c|c|c|}
\hline Regresi (a) & 1 & $203.203,1$ & $203.203,12$ & \\
\hline $\begin{array}{l}\text { Regresi } \\
\text { (b/a) }\end{array}$ & 1 & 8,743 & 8,743 & \\
\hline Residu & 30 & 824,132 & 27,471 & \\
\hline $\begin{array}{l}\text { Tuna } \\
\text { cocok }\end{array}$ & 14 & 273,432 & 19,888 & \multirow{2}{*}{0,577} \\
\hline Kekeliruan & 16 & 550,7 & 34,41 & \\
\hline
\end{tabular}

Uji Hipotesis

\begin{tabular}{lll}
\hline & & $F_{\text {tabel }}$ \\
$r_{\text {hitung }}=103,725$ & $r_{\text {tabel }}=0,3494$ & $=$ \\
& & 4,16 \\
\hline
\end{tabular}

Tabel 2 diatas menunjukan bahwa untuk uji keberartian di peroleh $F_{\text {hitung }}>F_{\text {tabel }}$ yaitu $(4,37>4,16)$, berdasarkan kriteria pengambilan keputusan yang telah diuraikan maka kesimpulan yang dapat diambil adalah persamaan regresi diatas memenuhi syarat keberartian, sedangkan untuk uji linieritas diperoleh $\mathrm{F}_{\text {hitung }}<\mathrm{F}_{\text {tabel }}$ yaitu $(0,577$ $<$ 4,16), sehingga kesimpulannya adalah persamaan regresi diatas tidak memenuhi syarat linieritas. Selanjutnya adalah hasil perhitungan untuk uji hipotesis, pada tabel diatas dapat diketahui bahwa nilai $r_{\text {hitung }}>r_{\text {tabel }}$ $(103,725>0,3494)$ sehingga keputusan yang diambil adalah menolak $\mathrm{H}_{0}$ dan menerima $\mathrm{H}_{\mathrm{a}}$ yang berarti terdapat pengaruh antara model pembelajaran snowball throwing terhadap kemampuan komunikasi matematis siswa.

\section{KESIMPULAN}

Berdasarkan hasil penelitian yang dilakukan penulis tentang pengaruh model pembelajaran snowball throwing terhadap kemampuan komunikasi matematis siswa, maka penulis dapat menyimpulkan bahwa model ini memberikan dampak positif terhadap kemampuan komunikasi matematis siswa. Hal ini didapatkan berdasarkan perhitungan uji hipotesis dimana harga $r_{\text {hitung }}=103,725$ dan $\mathrm{r}_{\text {tabel }}=0,3494$ karena $\mathrm{r}_{\text {hitung }}>\mathrm{r}_{\text {tabel }}(103,725>$ 0,3494) maka $\mathrm{H}_{0}$ di tolak atau $\mathrm{H}_{\mathrm{a}}$ diterima. Sehingga dapat disimpulkan bahwa terdapat pengaruh antara pembelajaran snowball throwing terhadap kemampuan komunikasi matematis siswa.
DAFTAR PUSTAKA

Arikunto, Suharsimi. 2013. Prosedur Penelitian Suatu Pendekatan Praktik. Jakarta: Rineka Cipta

Clara Dwi, dkk. "Peningkatan Kemampuan Komunikasi Matematis Melalui Pembelajaran Kooperatif Tipe Two Stay Two Stray". Jurnal Pendidikan Matematika. Vol. 5, No. 8, Mei, 2014.

Irmayanti dan Ardin Siagalan. 2011. Penerapan Model Pembelajaran Snowball Throwing dalam Meningkatkan Hasil Belajar Siswa. Serdang Bedagai. Jurnal Geografi. 1(1): $81-89$

Sari, Lisna Siti Permana. (September 2014). Pembelajaran Berbasis Masalah Untuk Meningkatkan Kemampuan Komunikasi Matematika Siswa Sekolah Menengah Pertama. Mosharafa:Jurnal Pendidikan Matematika, Volume 3, Nomor 3, Issn 2086-4280, 145 .

Syaripah. (September 2016). Pengaruh Persepsi Pembelajaran Matematika Terhadap Motivasi Belajar Siswa Dalam Bidang Matematika Di Sekolah SMA N 1 Curup T.P 2014/2015. Jurnal EduTech Vol. 2 No. 2.

Sugiyono. 2002. Metodologi Penelitian Administrasi. Bandung: Alfabeta

Sugiyono. 2010. Metode Penelitian Kuantitatif, Kualitatif, dan $R \& D$. Bandung: Alfabeta

Sukmadinata, Nana Syaodih. 2012. Metode Penelitian Pendidikan. Bandung: PT. Remaja Rosdakarya

Widayanti, Tri. 2014. Keefektifan Pembelajaran Model Snowball Throwing Berbantu CD Interaktif Terhadap Kemampuan Pemecahan Masalah. Semarang. Jurnal kreano. 5(1): 99-104 
Jurnal Serunai Matematika

Vol 12, No. 1, Maret 2020 e-ISSN 2620-9217 